Article

\title{
Fostering Generative Partnerships in an Inclusive Business Model
}

\author{
Rong Zhu ${ }^{1}$ and Sunny Li Sun ${ }^{2, *}$ (]) \\ 1 Department of Business Administration, Business School, Beijing Technology and Business University, \\ Beijing 100048, China; zhurong@th.btbu.edu.cn \\ 2 Department of Marketing, Entrepreneurship and Innovation, Manning School of Business, University of \\ Massachusetts Lowell, Lowell, MA 01854, USA \\ * Correspondence: li_sun@uml.edu
}

Received: 9 March 2020; Accepted: 14 April 2020; Published: 16 April 2020

check for updates

\begin{abstract}
How does a social venture build multiple partnerships among stakeholders to enable a wide range of social value propositions and alleviate economic inequality? We address this question by developing a new concept on generative partnerships, defined as the collaboration between nonprofits and business organizations to co-create social value proposition and attract enhanced collaboration to solve social issues in an inclusive business model. We study two Chinese cooperatives, Co-op Lishui Shangeng (L) and Co-op Wuyang Chunyu (W), to show how they created a social ecosystem through an inclusive business model. These two cooperatives have also developed co-brandings L and W, respectively. We find that hybrid organizations could generate partnerships among different agents to form a social ecosystem. Drawing on the generative relationship theory, we identify four stages of fostering generative partnerships: (1) a value blueprint, (2) a pilot demonstration, (3) scaling-up, and (4) snowballing. After developing propositions regarding directedness, heterogeneity, and interaction of agents, we further elaborate two common schemas on the process of generating hybrid partnerships in this social ecosystem.
\end{abstract}

Keywords: generative partnerships; inclusive business model; social ecosystem; cooperative

\section{Introduction}

Prominent researchers [1-3], business leaders [4], and non-profit organizations [5] have recognized that increasing economic inequality is a major problem in our times. Although research in this area has led to an improved understanding of the causes and consequences of inequality [1,2] more needs to be done to develop actionable business solutions to alleviate the problem.

Previous research has proposed an inclusive business model to help social and business organizations find solutions to include marginalized people into the value co-creation process as producers and customers [6-9]. This model has gone beyond traditional corporate social responsibility and philanthropy to expand access to goods and services in a sustainable way for those at the bottom of the pyramid (BOP). These marginalized people tend to suffer from "nonconsumption" - "where would-be consumers are desperate to make progress in a particular aspect of their lives, but there's no affordable and accessible solution to their problem" [10] (p. 38). Such sustainability-related issues have become embedded in formal organizational structures and procedures [11]. Government and non-profit organizations engage in hybrid multi-stakeholder partnerships for sustainable business and contribute to local economic, social, and environmental concerns [12]. This sustainability strategy is legitimate at the organizational level, but actors experience tension when implementing it [13]; thus, an inclusive perspective must be considered. 
The inclusion of the BOP into the process of value creation is a win-win model that helps alleviate poverty [5] while also benefitting firm performance [14]. The problem, however, lies with the difficulties of implementing this model $[5,15]$. To do so, businesses need to find ways to build a hybrid partnership and coordinate activities with vastly different stakeholders across countries and organizational boundaries [16-18]. Partners could range from local organizations that draw on local resources $[19,20]$ to those hybridized by global non-profit organizations that can quickly share information about best practices to local partners worldwide. Partners further include funders, nonprofits, networks, business, government, and social entrepreneurs [21]. This spectrum of partners or stakeholders tends to have vastly different goals, values, and practices, and yet they must find ways to coordinate their actions to include the BOP into the co-creation process. The United Nations' sustainable development agenda is influential in addressing the multi-stakeholder partnership approach [22].

Algoso (2015) [23] has suggested that "extrapreneurs" are needed to handle this complex coordination problem. Extrapreneurship is a hybrid partnership approach that goes beyond co-ordination or co-branding and starts with "the network and leverages (resources) ... to create a disproportionately greater development impact" [23]. Extrapreneurs have built coordinating and facilitating mechanisms among multiple actors and interest groups [24] and advocated for a new inclusive market with normative institutions such as mutual trust, professionalism, openness, and complementarity $[25,26]$. These hybrid partnerships and networks facilitate fund flows, diffuse best practices, and facilitate knowledge spillovers [24,27]. Multi-stakeholder partnerships are designed to solve social problems, and thus it is a challenge to define value propositions to each partner [28]. The degree of hybridity impact organizational outcomes in creating economic and social value [29].

Missing from this line of research on extrapreneurship is an in-depth understanding of the creation process of a hybrid generative partnership across stakeholders to develop an inclusive business model. Following Austin and Seitanidi (2012) [30] and Seitanidi et al. (2010) [31], we define generative partnership as a collaboration between nonprofits and business organizations to create a social value proposition and attract additional collaborations to mutually solve social issues in an inclusive business model.

Generative partnerships are hybridized by variant ideas, people, places, and resources that address large social challenges [32]. They are crucial for fostering creativity and innovation among different partners [33] and important for assessing social innovations in the production process [34]. Furthermore, generative partnerships may alter participants' view about the world, fostering innovation by leading to the emergence of new agents, artifacts, or institutions $[33,34]$ that form a social ecosystem $[35,36]$.

While we develop a novel concept of social entrepreneurship in this paper, we aim to contribute to an in-depth understanding of the process of creating hybrid generative partnerships by analyzing two cooperatives in China that created such a partnership. We particularly focus on how stakeholders in these cooperatives increased value to agricultural products through value propositions. The two cooperatives, Lishui Shangeng (co-op L) in Lishui county and Wuyang Chunyu (co-op W) in Wuyi county, have worked on establishing social ecosystems through promoting co-brandings L and W, respectively. In this process, stakeholders' mutual directedness played an important role in creating new value. Co-branding had many exploration examples, such as Washington Apple, Grown in Idaho Potato, Zespri Kiwifruit, and Japanese Kobe Beef. The difference is that when the cooperatives develop co-branding, they not only pursued financial benefits, but also aimed to achieve social benefits that included rural poverty alleviation and harmonious development.

Our study seeks to make three contributions. First, we extend the literature of inclusive growth $[37,38]$ by developing a new concept of generative partnership and related propositions on the ways that partnerships are generated to achieve an inclusive business model. Based on the literature of generative relationships $[33,39]$ and the grounded theory method, we first identify stage characteristics from observations and case interviews and then develop a four-stage model of generative partnerships in an inclusive business model. 
Second, our study contributes to an in-depth understanding of hybrid generative relationships in a social ecosystem $[33,39,40]$ by explaining how hybrid ties among different agents are related to the agricultural social ecosystem. This study also contributes to prior research by exploring how the social ecosystem can be established in an inclusive way. We go beyond existing work by suggesting that this type of social ecosystem not only creates value, but also helps to create inclusive development.

Third, this study contributes to the existing knowledge on generative relationships and inclusive business models by identifying two schemas (i.e., the generative potential of the relationships, and unexpected opportunities in co-creation) in the business-model institutionalization process and the social ecosystem. Beyond collecting data from interviews and archives, we followed anthropological observations to portray the two schemas involved in institutionalizing a generative partnership.

\section{Generative Partnerships in an Inclusive Social Ecosystem}

\subsection{Generative Partnerships}

An organization fostering generative partnerships within and across boundaries can produce novel joint value [33] and social impact. Lane and Maxfield (1997) [33] identified five essential preconditions to assess which relationships have generative potential: aligned directedness, heterogeneity, mutual directedness, permissions, and opportunity for common action. To create joint value, those involved in the relationship need a shared focus on an agent or artifact (aligned directedness). The relationship also needs to be able to combine differences among agents (heterogeneity of agents). Agents must develop a recurrent pattern of interactions from which a relationship could emerge (mutual directedness), and those involved in the relationship need to have discursive relationships (permissions). Finally, agents must have opportunities to interact during activities to discuss matters of common interest (opportunity for common action) [33,34]. In the inclusive business model, all participating agents must orient their activities toward a common social value proposition and differ from one another in key attributes. The participants also must be interested in forming potential generative partnerships, discuss key themes in requests, orders, and declarations, and engage in joint actions to form new competencies.

Opportunities and ecosystems allow organizations to create new social value propositions through collaborating with multiple parties that create complex products and services [41]. The social ecosystem integrates ecology and innovation as an organic whole for sustainable development [42]. While generative partnerships promote social value propositions in the business model, the partnerships also build an inclusive social ecosystem defined as "the collaborative arrangements through which firms combine their individual offerings into a coherent, customer-facing solution" [41,43]. Hence, generative partnership includes both the value-creating process [39] and the value-capturing process [41].

\subsection{An Inclusive Social Ecosystem}

To explain the social value proposition, we introduce the concept of ecosystem to emphasize dynamism and interdependence. First, the dynamic perspective of an ecosystem requires participants not only to focus on the institutional influences and marketing factors, but also on the relationships between focal enterprises and marginal enterprises, as well as enterprises and the environment [39,44]. More specifically, companies that want to occupy "bottleneck" positions [45] in the game must implement influencing, supervising, and upgrading strategies $[46,47]$ to ensure that value propositions are achieved and captured [41]. Second, the social ecosystem concept highlights the mutual dependency of components. The components include complementary inputs, and composing and determining ecosystems by loose interconnection $[43,48]$. The ecosystem establishing process remains an obstacle to the realization of mutual dependency, which refers to the dilemma of the first mover. That is, if the benefits of ecosystems depend on the interaction of components, how could one be persuaded to take the lead and contribute to the framework construction [41,49]?

The very essence of the solution is to display a "blueprint" for the emerging social ecosystem, which represents the adage, "give a man a fish and you feed him for today; teach a man to fish and you 
have fed him for a lifetime" [22]. Potential stakeholders could therefore explicitly acknowledge the value proposition of the focal companies [50,51]. The blueprint guides the ecosystem on what tasks to accomplish, how to accomplish them, the persons involved, and the benefits gained [43]. At the same time, to properly preserve a disproportionate share of collective value creation [45], companies should strive to be leaders by introducing cutting-edge technologies, creating business models, and exclusively holding the "bottleneck" position. In the social ecosystem, external enablers have "the potential of playing an essential role in eliciting and/or enabling a variety of entrepreneurial endeavors by several (potential) actors" [52] (p. 683). Multiple emerging ventures can benefit from external enablers, which create and build regulatory change, technological and demographic change, socio-cultural change, and natural-environmental change. A mechanism of external enablers in venture creation is to allow the creation of new artifacts, such as business models, devices, and functionality [53].

We identify four stages that these organizations followed to achieve an inclusive business model during the period of 2014 to 2018. These four stages include the value blueprint stage, the pilot demonstration stage, the scaling up stage, and the snowballing stage. See Figure 1 for a summary of these four stages. Our four-stages framework was mainly generated from the literature of generative relationships [33,34]. We also followed the method of the grounded theory in inductive reasoning to identify the stage characteristics based on observations and case interviews.

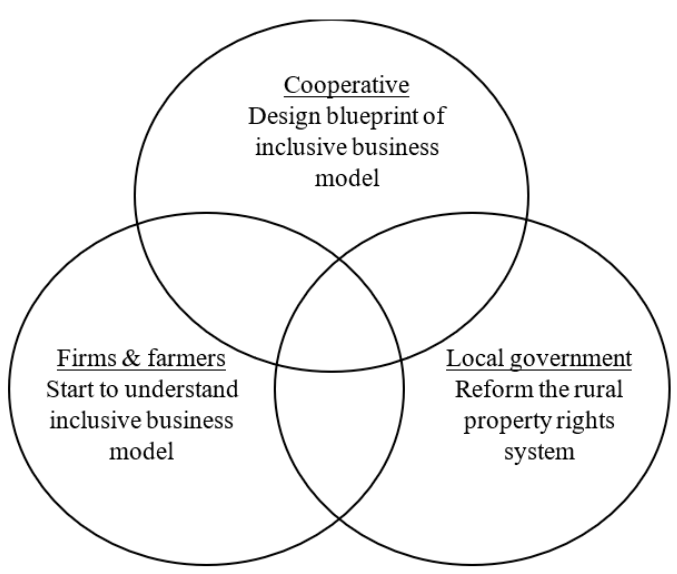

(a)

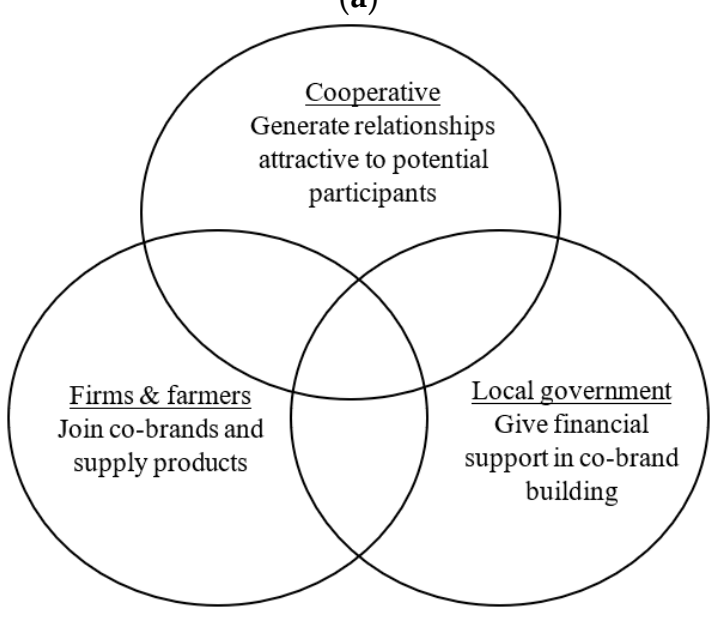

(b)

Figure 1. Cont. 


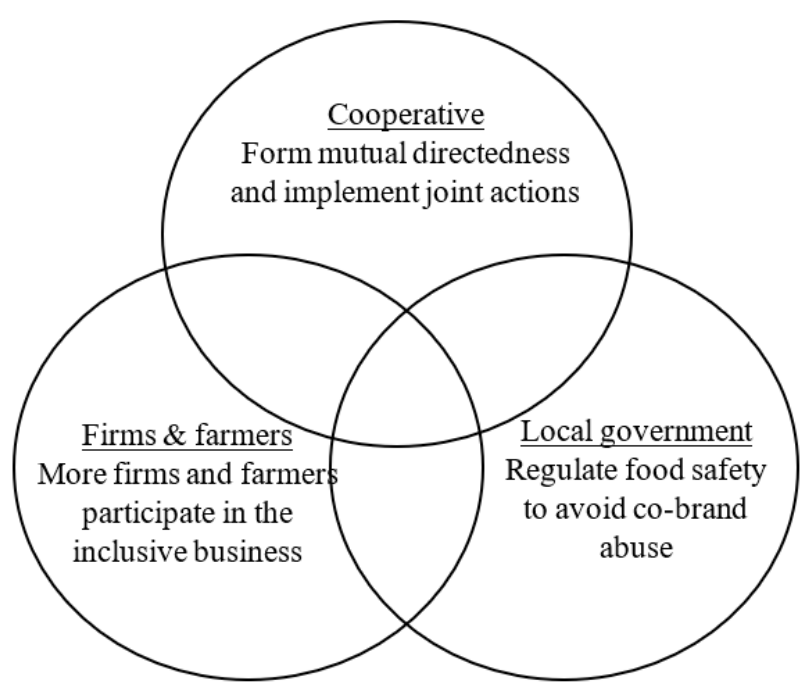

(c)

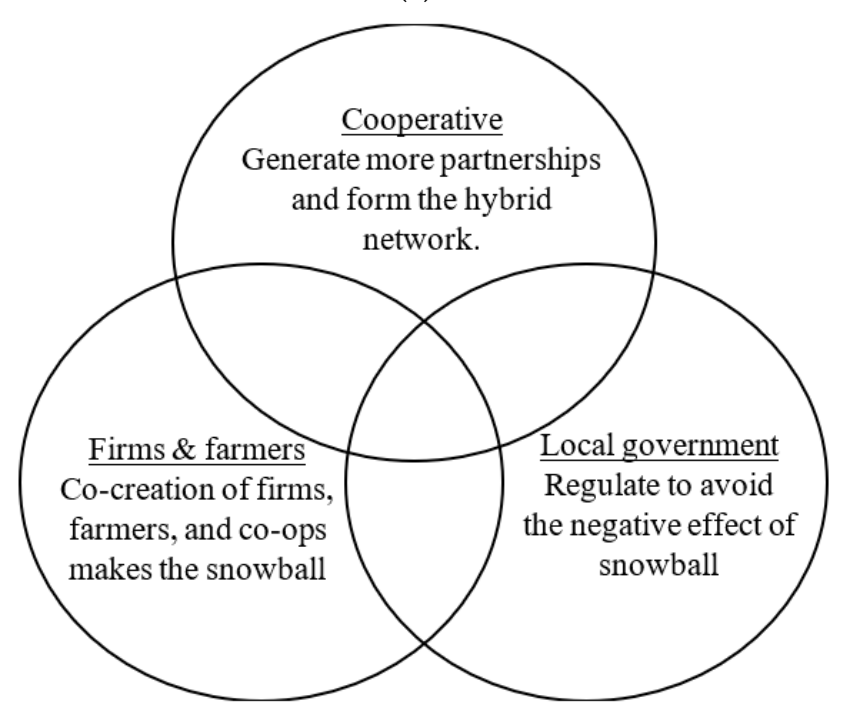

(d)

Figure 1. Four stages of the inclusive business model development. (a) The first stage: value blueprint; (b) The second stage: pilot demonstration; (c) The third stage: scaling up; (d) The fourth stage: snowballing.

\section{Methods}

\subsection{Research Design}

We relied on two case studies to identify the dynamics of generative partnership and engage in a theoretical generalization $[54,55]$. The theory generated from this case comparison method was more robust and the theory was only generated from a single case. The approach used in this study fits the contextualized approach recommended by Welch et al. (2011) [56]. The multiple sources drawing upon quantitative and qualitative information allowed us to trace strategic developments in a changing context [57]. We used participant observation, interviews, and documentary analyses in our research for developing contrasts within the two cases. The data were organized around certain topics, key themes, or questions, and were examined to see how far they fit or fail the categories. Three members of our research team were involved in developing the coding schemes. We coded and analyzed the data independently and iteratively to consistently check the reliability and validity. After three coders developed a high inter-rater reliability on the new concept construction, we reached 
agreement on theoretical saturation. This scientific research design enabled us to identify particular contextual drivers and corporate developments and how and why they influence each other with greater confidence.

\subsection{Case Selection}

This paper focuses on two cooperatives that we labeled co-op Land co-op W, and Table 1 shows their entrepreneurial processes. The two co-ops are located in Zhejiang Province where co-branding has been actively developing. Co-op $\mathrm{L}$ initiates co-branding $\mathrm{L}$ in prefecture-level cities in China with a first mover advantage. As a representative of county-level regional public brands, co-op W's success can be replicated to other county-level co-brandings. Both co-ops have undergone the four stages shown in Figure 1. We conducted a cross-case comparison analysis on the basis of case method, sought similarities and differences in the inclusive business models of China's co-branding, and continuously enriched the case conclusions.

Table 1. Co-op L and Co-op W Memorabilia.

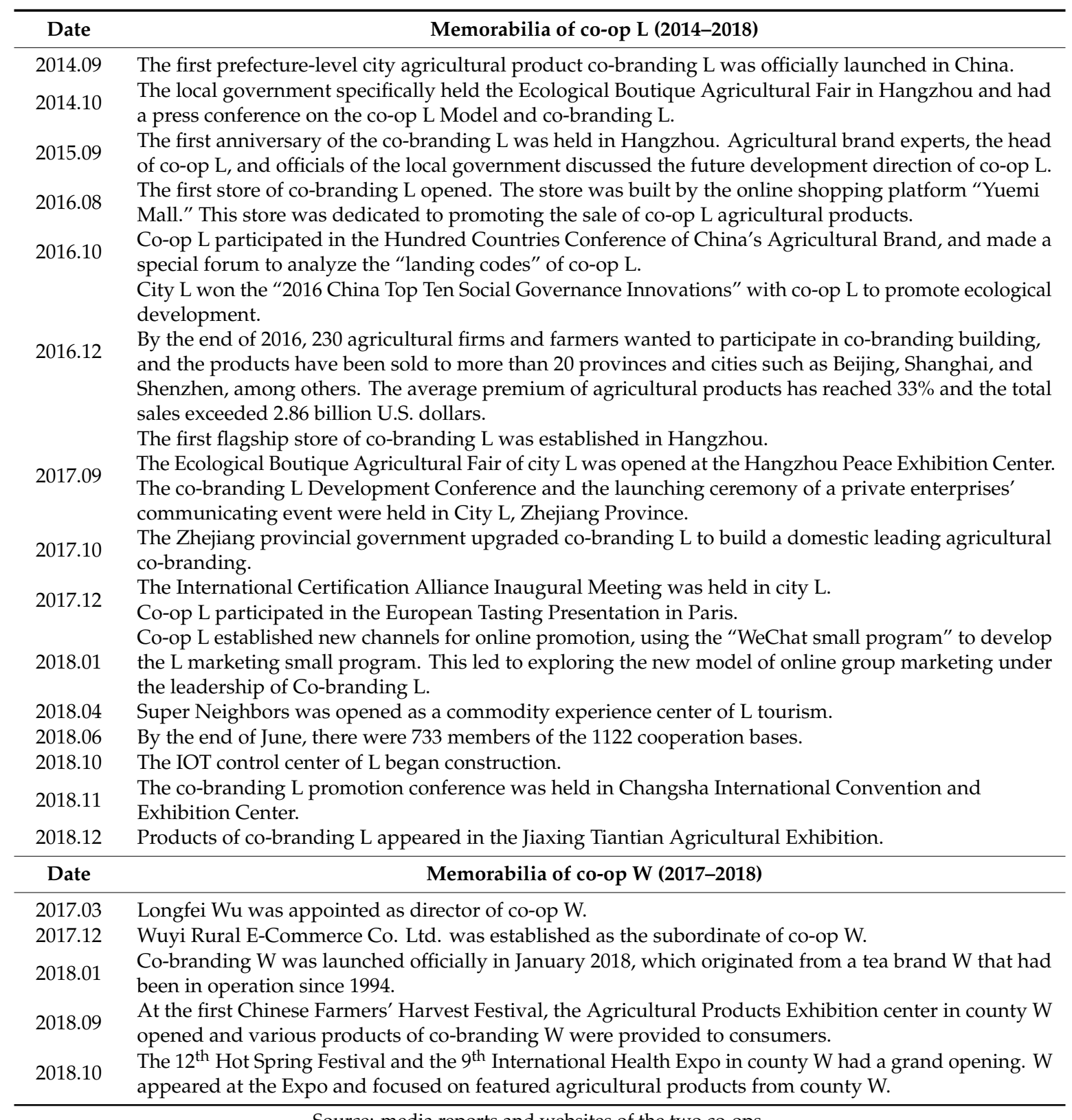




\subsection{Data Sources}

For our two cases, we relied on a combination of real-time observation and interview data as well as retrospective archival data (Table 2). The two authors began the research by appearing at these two cooperatives, observing them, and talking to residents. After initial conversations with the leaders of the two cooperatives, we were allowed to attend meetings and exhibitions.

Participant observation and archival material. We researched co-op L and co-op W on several occasions, interviewing agents, taking notes, and writing theoretical memoranda. For example, during a participant observation at co-op $\mathrm{W}$, we observed the exhibition stands of five agricultural firms, chatted with consumers, and observed their purchase behavior. We went to five villages to observe farmers. We noted who associated with whom, the relationships between various individuals and groups, and the issues that seemed to be salient to stakeholders. In addition, we examined archival material, including financial records, pamphlets and posters, meeting handouts, and so forth.

Semi-structured interviews. We engaged in in-depth investigations and observations in co-op $\mathrm{L}$ and co-op $\mathrm{W}$. We conducted semi-structured interviews with two managers that had a deep understanding of co-branding development. During the participant observation, we asked five leaders of five agricultural firms that were cooperating with the two co-ops, and they agreed. In addition, we conducted interviews with six employees of the two co-ops, seven farmers who cooperated with both two co-ops, and 16 consumers shopping at co-op L and co-op W, which was a random process. We analyzed the entrepreneurship processes of co-op $\mathrm{L}$ and co-op $\mathrm{W}$ from the user perspective.

Media coverage. We relied on search engines to collect public documents of the two co-ops and other agents including website information, internal magazines, and articles in the local media about co-op L and co-op W.

Table 2. Data Summary.

\begin{tabular}{|c|c|c|c|c|}
\hline \multirow[t]{2}{*}{ Company file and media report summary } & Co-op L & Co-op W & Co-op L & Co-op W \\
\hline & \multicolumn{2}{|c|}{ Number } & \multicolumn{2}{|c|}{ Time range (year) } \\
\hline Search engine & 1 & 1 & 2014-2018 & $2017-2018$ \\
\hline Annual report & 4 reports & 1 report & $2014-2018$ & 2018 \\
\hline Media coverage & 24 articles & 11 articles & $2014-2018$ & $2017-2018$ \\
\hline \multirow[t]{2}{*}{ Observation and interview summary } & Co-op L & Co-op W & Co-op L & Co-op W \\
\hline & \multicolumn{2}{|c|}{ Number } & \multicolumn{2}{|c|}{ Dialogue and Interview time (hours) } \\
\hline Observation by the two authors & 3 months & 3 months & 16 & 16 \\
\hline Managers of the two co-ops & 1 person & 1 person & 2 & 2 \\
\hline Employees of the two co-ops & 3 persons & 3 persons & 3 & 3 \\
\hline $\begin{array}{l}\text { Leaders of agricultural firms cooperating } \\
\text { with the two co-ops }\end{array}$ & 3 persons & 2 persons & 3 & 2 \\
\hline Farmers cooperating with the two co-ops & 2 persons & 5 persons & 2 & 3 \\
\hline Customers of the two co-brandings & 6 persons & 10 persons & 2 & 2.5 \\
\hline
\end{tabular}

\subsection{Data Analysis}

We conducted a detailed analysis of the interviews to better understand the entrepreneurship processes and business models. First, we transcribed the interviews to cover the past, present, and future development, as well as the relationships and dependencies among various stakeholders in the social ecosystem. We relied on the constant comparative method [58] and triangulated the emerging insights between different data sources, contexts, and iterations of the same situation.

We next combined information derived from all the different sources, drafted timelines, and explored underlying changes. We used multiple sources (governments, industry, markets, competitors, media reports, etc.) to gain a deeper understanding of co-branding practices. For example, we analyzed the impact of government policies, market environment changes, and media reports on co-branding development. Three research team members independently coded the organizational-level data to ensure reliability. We present analyses in a Gioia-style data structure (Figure 2) [59]. To be specific, 
the first-order analysis adheres faithfully to informants' description, which is similar to the process of open coding [60]. The second-order themes were taken from similarities and differences among many concepts and categories, which is similar to Strauss and Corbin's (1998) [60] axial coding. We used researcher-centric concepts and themes in the second-order analysis. The tandem reporting from informants and researchers allowed a qualitative demonstration of the links between data and themes. Higher-level aggregate dimensions were distilled from the second-order themes. Finally, we distributed the case to the people involved in the survey and interviews and summarized their feedback. Figure 2 presents the final data structure resulting from the data analysis. We identified three dimensions of generative partnership: directedness, heterogeneity, and interaction by taking iterative steps among the data, literature, and theoretical ideas [61]. Directedness originates in common blueprint and social value proposition. Heterogeneity refers to combining differences between agents in terms of expertise or attributes for generating relationships. Interaction derives from the processes of agents working together. Generative partnership requires and produces the following intangibles in interactions: trust, communication, learning, and joint problem solving.

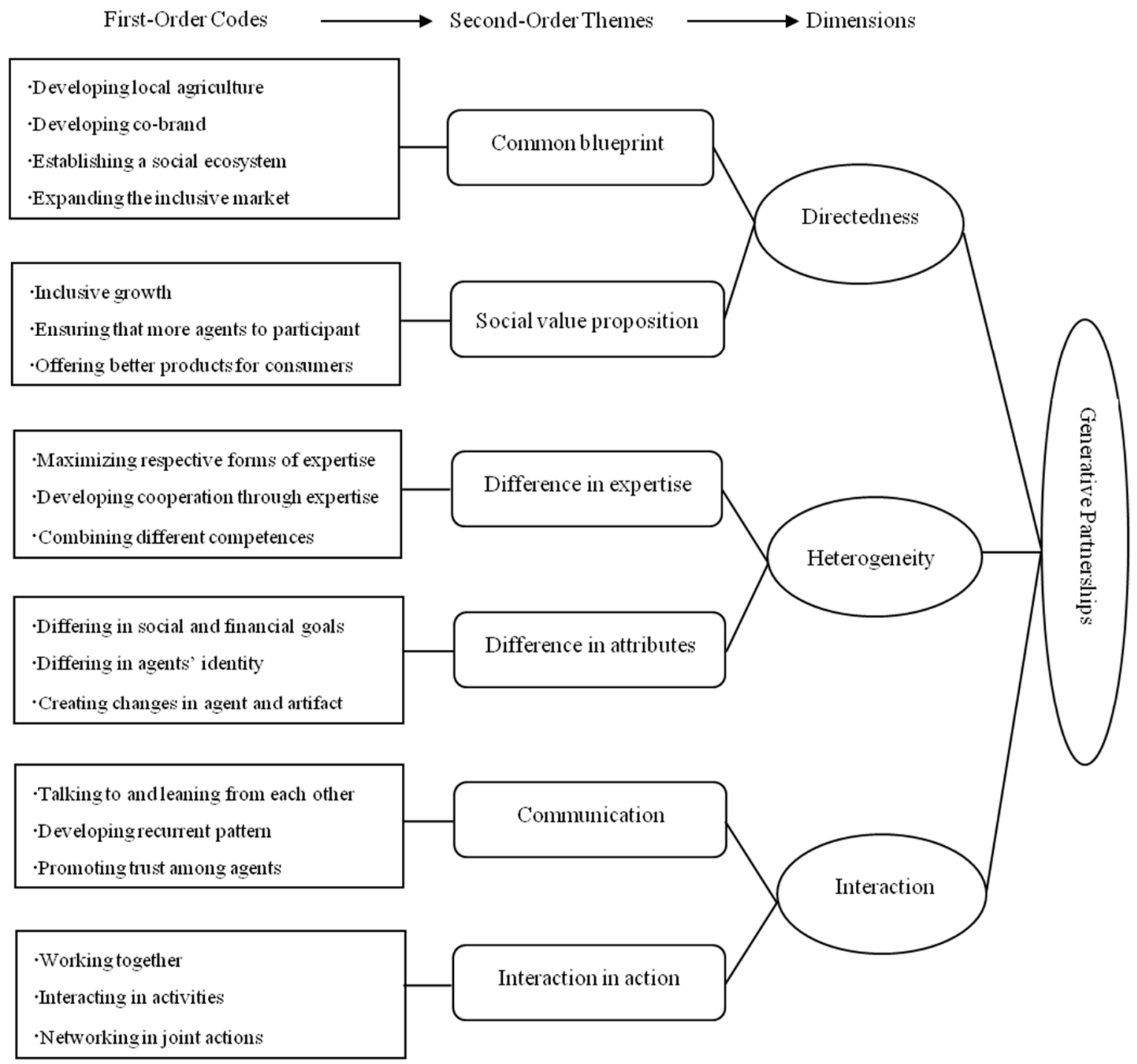

Figure 2. Constructing generative partnerships.

When we coded the four stages, we stimulated the induction through these questions: What is the relationship of one stage to another? How do the different stages compare and relate to the concept of 
generative relationships? What are the properties of the stages and who (which stakeholder) takes what kind of action? What would happen if the first stage finishes? How do different events evolve over time? What could lead to the next stage of generative relationships?

\section{An Inclusive Business Model of Ecosystem Creation}

The social ecosystem is constantly evolving and can be understood from a dynamic interaction perspective. Social innovation processes are guided and diffused by formal and informal "scaffolding structures," that include organizations such as associations, as well as regular events such as trade fairs and exhibitions [62]. In our inclusive business model, such structures are necessary when agents manage uncertainty by jointly shaping the direction of local agricultural development. The inclusive business model has the potential to generate innovations when agents have a common focus on the same artifacts, such as co-branding and e-commerce platforms (aligned directedness), but they differ in expertise or attributions, such as by having different social or financial goals (heterogeneity). Agents form recurrent schemas of interactions that could generate relationships (mutual directedness). Agents have discursive interactions such as requests, negotiations, declarations, agreements (permission), and the potential to create opportunities to work together on activities, such as exhibitions and trade fairs (joint action). The two cases discussed in this paper concern inclusive agricultural development models, both of which experienced the four stages of development. The models have been implemented in Chinese regions where the clusters of private agricultural firms and flourishing of organic agricultural production characterize the economic structure. We use the notion of generative partnerships introduced by Lane and Maxfield (1997) [33] to describe the dynamics of social innovation and compare the two cases in the four stages in Table 3.

Table 3. Comparison of the Two Cases.

\begin{tabular}{|c|c|c|}
\hline & Co-op L & Co-op W \\
\hline \multirow[t]{2}{*}{$\begin{array}{l}\text { The first stage: } \\
\text { value blueprint }\end{array}$} & $\begin{array}{l}\text { Co-op L establishes rural property rights } \\
\text { trading platform to transfer land-use } \\
\text { rights. }\end{array}$ & $\begin{array}{l}\text { Co-op W uses the strategy of "one village, } \\
\text { one product" to build the co-branding. }\end{array}$ \\
\hline & \multicolumn{2}{|c|}{$\begin{array}{l}\text { Co-ops } \mathrm{L} \text { and } \mathrm{W} \text { develop local agriculture by co-branding management and green } \\
\text { development, which are supported by local government. }\end{array}$} \\
\hline \multirow[t]{2}{*}{$\begin{array}{l}\text { The second stage: } \\
\text { pilot demonstration }\end{array}$} & $\begin{array}{l}\text { Co-op L establishes data center to offer } \\
\text { service from land to table for firms, } \\
\text { farmers, consumers, and governments. }\end{array}$ & $\begin{array}{l}\text { Farmers trust co-op W, while some firms } \\
\text { hesitate to trust and participate in } \\
\text { co-branding. }\end{array}$ \\
\hline & \multicolumn{2}{|c|}{$\begin{array}{l}\text { Co-ops } \mathrm{L} \text { and } \mathrm{W} \text { select locally welcomed agricultural products to perform pilot } \\
\text { demonstration and monitor co-branding building and product quality. }\end{array}$} \\
\hline \multirow[t]{2}{*}{$\begin{array}{l}\text { The third stage: } \\
\text { scaling up }\end{array}$} & $\begin{array}{l}\text { Co-op L establishes quality and safety } \\
\text { information management platform to } \\
\text { trace products. }\end{array}$ & $\begin{array}{l}\text { The demonstration works and firms learn } \\
\text { that there will be win-win cooperation. }\end{array}$ \\
\hline & \multicolumn{2}{|c|}{ Co-ops L and W expand their online market, while opening stores in the community. } \\
\hline \multirow[t]{2}{*}{$\begin{array}{l}\text { The fourth stage: } \\
\text { snowball }\end{array}$} & $\begin{array}{l}\text { Co-op L helps farmers and firms to get } \\
\text { financial service. }\end{array}$ & $\begin{array}{l}\text { Co-op W attracts more farmers and firms } \\
\text { to build co-branding. }\end{array}$ \\
\hline & \multicolumn{2}{|c|}{$\begin{array}{l}\text { Co-ops } \mathrm{L} \text { and } \mathrm{W} \text {, local governments, and business partners form their respective social } \\
\text { ecosystems together. }\end{array}$} \\
\hline
\end{tabular}

\subsection{The First Stage: Value Blueprint}

Both co-op L and co-op W are in relatively underdeveloped areas because of their remote geographical location and poor traffic conditions. Traditional farming modes are still used in many villages, so although agriculture in the areas of these co-ops is small and scattered, it is also traditional and organic. The co-ops' advantage lies in the high quality of their agricultural products, not in their size or output. Developing co-branding for high-quality agricultural products serves as a starting 
point for developing the local agriculture. Co-branding is not only a symbol, but also an ecological value proposition and a core embodiment of organic agriculture. To converge multiple elements in social value propositions, the two co-ops need to generate an understanding and agreement among partners regarding how these elements should come together. Co-op L and co-op W launched their value blueprints (i.e., building co-branding $\mathrm{L}$ of ecological agricultural products and upgrading local agriculture; and promoting local agriculture by co-branding $\mathrm{W}$, high-quality agricultural products and various channels) in 2014 and 2017, respectively. Both were able to manage the process of mobilizing internal and external resources. Externally, the two co-ops obtained the subsidy from the local government and other agents to construct co-brandings, while seeking new strategies and project implementers internally. In the initial stage of the construction of the co-op L social ecosystem, co-op L decided to develop local agriculture by production standardization, product refinement, co-branding management, market diversification, and green development according to the development goals proposed by the local government. Through publicity, agricultural firms and farmers gradually understood and joined the social ecosystem. There were 96 organic certification enterprises and 186 products in county $\mathrm{W}$ in 2017. County W put the construction goal of "the first county of organic agriculture" forward to promote the development of modern agriculture and steadily realize agricultural efficiency and income increase. The strategy of "one village, one product" used by co-op $\mathrm{W}$ was key in achieving this goal. W's co-branding was used as the leader in the journey to implement new missions and organize more agricultural firms and farmers to sell locally distinctive agricultural products in exhibition centers and online sales.

The social value proposition presented by the two co-ops was attractive to agricultural firms, farmers, and local governments, among which interactions are crucial to form aligned directedness. In 2013, the Chinese central government proposed that farmers should be given the right to possess, use, benefit, or transfer farmland that had been contracted under the premise of adhering to the strictest cultivated land protection system. The local government of co-op L took the lead in implementing this new institutional arrangement and removed obstacles for the development of co-branding in 2013. In the same year, co-op L started to provide information releases, registration, business consultation, and agency services for property rights transfer of farmland in rural areas. For example, a company called Dade rented farmers' land and grew herbal medicine. Dade rarely used mechanical operations, but employed villagers to sow, water, weed, and harvest. In this way, rural ecology is protected, farmers receive both rent and wages, and Dade could provide organic products to consumers. In general, environmental protection and job creation became the requirement for importing projects in local city Lishui.

This institutional change guides the flow of capital to the rural area, optimizes the allocation of rural resources, and safeguards farmers' property rights and interests. Agricultural firms have opportunities to rent more farmland to expand plantations. Farmers that continue to plant have channels to participate in the co-branding ecosystem. These agents are "tightly interdependent and mutually supportive" [63], interact dynamically to find their place in the ecosystem, and establish relationships with other agents and artifacts.

These agents differ from each other in some respects. Heterogeneity of agents' attribution can generate new kinds of attributions. Combining different types of competence can generate new types of competence in agents' interactions. As a hybrid organization, the two co-ops need to obtain financial return to be self-sustainable, as well as a goal to expand their inclusive markets to develop local agriculture. The inclusive business model helps marginalized populations to participate in and benefit from economic activities. The two co-ops proposed value propositions for the social ecosystem in order to leverage the power of market competition in addressing social problems. Although firms and farmers mainly obtain economic benefits, some of them understood and identified the value blueprint, and then participated in the social ecosystem. Based on the above, we suggest the following propositions: 
Proposition 1: Social value proposition in an inclusive business model builds the dynamic interactions among different agents and promotes the formation of directedness in co-branding building.

Proposition 2: Agents' directedness in a common blueprint helps to develop the social ecosystem, regardless of agents' different ways of thinking or viewing the world.

\subsection{The Second Stage: Pilot Demonstration}

Innovation is driven by interactions in generative partnerships, especially among heterogeneous agents that can induce changes. In the two cases, interaction space was designed to create an environment that enhances generative potential. Through interviews and observation, we explored agents' interaction within the cooperative network and found that monitoring is important for fostering relationships, which gives further rise to changes and innovation. As focal agents, co-ops $\mathrm{L}$ and $\mathrm{W}$ guide and monitor in co-branding development, establishment of standards, and product quality. In the pilot phase, co-op L and co-op W respectively selected Suichang bamboo shoots and Xuanping lotus seeds, which are well known locally, and focused on product quality and avoid the "public land disaster." A farmer who planted 100 acres of Xuanping lotus seeds told us, "I plant organic Xuanping lotus seeds in Huyuan Village, which has been a royal tribute to the Qing Dynasty because of its superior quality. The biggest challenge is the competition with non-organic lotus seeds, because it's difficult for consumers distinguish the two products. The local government regulates business operation and requires producers to identify organic and non-organic lotus seeds. Now co-op W can tell consumers the difference, which helps us a lot, and I try to contribute to this co-branding."

Generative partnerships contribute to the innovation dynamics, which are affected by institutions and participating agents with similar, heterogeneous, or complementary competencies. The innovation dynamics foster regulative reproduction and diffusion of entities that is important to the social ecosystem. While the two co-ops established co-brandings, some farmers and agricultural firms worked with the co-ops to supply agricultural products in accordance with a uniform appearance, quality, and variety. Co-ops and agricultural firms cooperated to expand both the visibility of different agents through parent-child brands and the sales channels of agricultural products. In the pilot demonstration stage, some agricultural firms did not trust the co-ops, especially those firms with their own brands and distribution channels. One of the main difficulties mentioned by the interviewees is the concern by that the co-brandings were newly established and did not have broad influence. They were suspicious about whether the co-ops could really generate partnerships in the social ecosystem. Additionally, we also discovered during our interviews that farmers were concerned with three questions: How much could the co-ops help farmers to sell? Was it possible for farmers to be responsible only for planting and not for other tasks such as packaging and marketing? How would farmers get paid?

In order to alleviate firms' and farmers' doubts, co-op W invited the farmers and firm owners who participated in the early stage of co-branding building to share their experiences. For example, co-op W signed contracts with farmers to pay $30 \%$ in the first month for their products, $50 \%$ in the second month, and $20 \%$ in the third month. Farmers did not have to worry about the selling of products after the products were handed over to co-op W. However, farmers needed to control the quality of their products and ensure the output. There are videos in shopping centers that are broadcasting production and processing of agricultural products and establishing information connections between farmers and consumers. Activities such as exhibitions and consumer trial have been used by the two co-ops to help farmers and firms to display their products in the market system. Additionally, these events have allowed consumers to taste food before buying it and give feedback to producers in real time. The events allowed agents with complementary resources and different capacities to work together, develop the inclusive business model, and implement partnerships [31]. 
Proposition 3: Heterogenerous agents see one another as enablers in changing, modifying, and promoting partnerships to become generative.

\subsection{The Third Stage: Scaling-up}

The inclusive business model and the social ecosystem are embedded in institutions and the market. Institutions, as the rules of the game [64], enable and support market-based activities [65]. Institutions could also be conceived as targeting its own generative character or targeting network activity $[66,67]$. The market is a locus of exchange activities, where agents buy and sell products at a price that reflects supply and demand equilibrium. Although the market works as an engine for economic growth, and market-based activities play an important role in social progress and human development [19], institutional voids are a source of market exclusion. It is thus crucial to build a new market structure and rely on legitimate agents to build inclusive markets [26]. The inclusive business model we explored in the two case studies is an application of developing an inclusive market by creating space for interaction and recombining norms and traditions. To be specific, building equal communities as opposed to having hierarchical ones expands the two co-ops' mobilization approach. Free and equal places are created to eliminate farmers' beliefs about the market's exclusive nature. For example, in referring to the agents of $\mathrm{W}$, a farmer told us that, "we had learned how to access the broader market through helping each other and getting together rather than just selling products at the roadside." Some farmers live at the BOP in rural areas and are considered to be producers-not crucial participants of market-based activities. The two co-ops have helped to build farmers' self-awareness, foster farmers' mobilization in the social ecosystem, and show them how to benefit from the value chain. The local government works together with the two co-ops to offer various training courses for farmers. The head of the Baozhong Family Farm in County W told us in October 2018 that, "The rice here has organic certification, but last year's rice hasn't been sold out yet. It's difficult to exploit the market by myself, so I cooperate with Co-op W. The co-op helps my farm to become known to more consumers. Sometimes Co-op W asks me what they can do to help famers increase incomes, and we discuss together how to make the inclusive business model work better. I have learned a lot in the skills and business training course."

With the development of an inclusive market and the redefinition of existing norms, the inclusive business model achieved rapid growth in China from 2013 to 2018. Many creative ideas came from the relationship that developed between the marketing staff and the product consumers. Farmers in Lishui and Wuyi made higher and more stable income, which also enhanced their loyalty to consumers and supporters of these two co-brands. As economic development in China grows, the need for more ecological agricultural products is also increasing, and middle-class consumers focus more on the origins and quality of food. All of the products with co-branding $L$ have a code that consumers use to trace products on the quality and safety information-management platform established by co-op L. The platform works as bridge connecting producers and consumers. Additionally, the co-op L formulated storage and transportation standards, including the picking, storing, and transporting of products, and has also standardized testing standards.

Both the co-ops L and $\mathrm{W}$ have expanded the online market, while opening stores in their communities. Both have found some potential consumers who advocate the ecological life concept. The value proposition that has been "experienced through heterogeneous interaction" [68] between firms and consumers has been gradually accepted. In the first two stages, producers and consumers have been mainly local, while in the scale-up stage consumers in other cities have joined in the ecosystem, which poses a challenge to co-branding development and product control. We then suggest the following.

Proposition 4: Generative partnerships take agents to higher levels by interactions in the social ecosystem when the partnerships are in a favorable environment. 


\subsection{The Fourth Stage: Snowballing—Developing a Hybrid Network}

The snowball effect is a process that starts from an initial state of small significance and then become larger, graver, or more serious. The snowball effect has been studied in turnover [69], political and economic reforms [70], supply chain integration [71], and so forth. In the social ecosystem, the patterns of multiple partner formation are not independently distributed across different groups. The firms, NGOs, or hybrid organizations are not independent actors. To create social value propositions, their interactions affect each other in behaviors and contributions. Moreover, the degree to which others are influenced depends on the generative partnerships. One action or partnership event can cause many similar actions or partnership events under a faster rate. This could generate a virtuous cycle. For example, Ohanyan (2008) [27] (p. 62) suggested the NGOs and multiple stakeholders could build a hybrid coordinating network in the following way: "When cooperating with such donors within networks, the implementing NGOs find themselves, willingly or unwillingly, advancing "best practice" norms often developed within these large donor organizations. Therefore, the choice of a particular policy and its implementation can be strongly influenced by the composition and members of the network in which the NGO or any other implementing agency is operating."

The two co-ops offer other participants, especially farmers, access to a co-branding service that was previously unaffordable or unreachable. This accessibility has a profound influence on economic development for the region as well as on participants' wealth increases. Drafting more agents into the social ecosystem, "over time, are far more effective at triggering sustainable prosperity" [10]. The social ecosystem leverages the inclusive business model and value chain that focus on value propositions before profitability and thus ensures more agents to participate. All the agents in the social ecosystem build network capacity by understanding, responding, and contributing to the ecosystem. The accumulation of these actions creates the need to increase network capacity [22]. We then suggest the following.

Proposition 5: In the snowballing stage, all agents in the social ecosystem contribute to the network capacity beyond the respective roles of directedness, heterogeneity, and interaction.

\subsection{Two Schemas Institutionalizing Hybrid Partnerships}

Based on the abovementioned exploration of the two co-ops and the social ecosystem, we find two inclusive business model schemas in institutionalizing different logics: generative potential of the hybrid partnerships [66] and the unexpected opportunity in co-creation.

The first schema is the generative potential of hybrid partnerships. Development of the two co-ops goes through four stages, during which partnerships are continuously generated. At the beginning, in addition to the co-ops and local governments, a few farmers and enterprises participate in the co-brandings. Later, more farmers, enterprises, and consumers join the open social ecosystem and gradually form the snowball effect. The social ecosystem constructed through generative partnerships is dynamic and could grow sustainably. The main function of external enablers is to trigger prospective entrepreneurs to start a new venture. In the two case studies, farmers hoped to make a fortune with the inclusive business model when market economy is developed in Chinese villages. They have more easily accepted the strategy proposed by the co-ops and became prospective entrepreneurs in the social ecosystem [53].

The second schema is an unexpected opportunity in the co-creation process. The inclusive business model is initially generated by and for a local market. All the business-model participants work hard to understand the market and offer healthy and safe products. Although they make use of organic products in the region, the inclusive business model is not fundamentally about taking advantage of organic products to make profits. In fact, over time-as relationships spread and generate through the ecosystem - sales and prices increase through co-branding building. The inclusive business model generates local jobs in marketing, sales, distribution, and design that fuel the inclusive growth of the 
local economy. External enablers help shape the two co-ops' products or market offerings, as the food safety social movement stimulates start-ups around traditional agricultural planting and organic food by reducing the social legitimacy of the existing agricultural mode that relies on chemical fertilizers and pesticides.

\section{Discussion}

\subsection{Findings}

Based on the two in-depth case studies, we reach three important conclusions. First, hybrid organizations, such as co-ops, could generate variable partnerships with different agents and together form an ecosystem that benefits all agents. Co-ops need the support of other agents to promote an inclusive business model. Co-ops, supported and encouraged by local governments, mobilize farmers and firms to participate in co-branding building by bringing better prospects to all agents. Second, the inclusive business model and the social ecosystem are not static but rather co-evolve from the interactions of various agents. In the four stages of the inclusive business model, the social ecosystem co-evolves by generating social value propositions and obtaining participant interactions. Third, directedness, heterogeneity, and interactions among different agents are essential to generative partnerships. Different agents, beyond their own value, play a part in the social ecosystem formation. Abandoning the orientation of maximizing enterprises' profits, social entrepreneurs, as "extrapreneurs," develop the inclusive business model, which is a positive improvement on traditional capitalism.

Our paper makes three contributions. First, we contribute to the business model literature by discussing it in a social and inclusive context $[37,38]$. We analyze the inclusive business model in four stages and describe how partnerships are generated in the model development that create an inclusive framework involving agents with minimal qualifications in the business model. The inclusive business model reflects "designed, novel, nontrivial changes to the key elements of a firm's business model and/or the architecture linking these elements" [72], and helps us to answer the question of how one can find inclusive growth opportunities in poor economies [73]. The inclusive business model transfers those at the bottom of the pyramid into consumers and producers, creates new markets, generates relationships, and then builds institutions. Inclusive business models have many best practices, such as microfinance. This paper expands inclusive business models to the context of agricultural industry and shows the generative potential of partnerships in forming the social ecosystem.

Second, we develop a novel concept of "generative partnerships" under an opportunity co-creation framework [74]. We provide a comprehensive comparison of the concepts of opportunity discovery and opportunity co-creation in Table 4. This table includes definitions, elements of opportunity, theoretical foundations, levels of analysis, and the type of opportunity considered by the two theoretical frameworks. 
Table 4. Comparison between Opportunity Discovery and Opportunity Co-creation.

\begin{tabular}{|c|c|c|}
\hline & $\begin{array}{l}\text { Opportunity Discovery for Poverty } \\
\text { Alleviation }\end{array}$ & $\begin{array}{l}\text { Opportunity Co-creation in Generative } \\
\text { Partnership }\end{array}$ \\
\hline Definition & $\begin{array}{l}\text { Possibility of creating new means when } \\
\text { competitive imperfections exist in the factor } \\
\text { or product markets [75] }\end{array}$ & $\begin{array}{l}\text { Increased opportunity structure implies } \\
\text { more space and fewer constraints for the } \\
\text { marginal consumer/farmer to exploit and } \\
\text { engage in entrepreneurial activities. }\end{array}$ \\
\hline $\begin{array}{l}\text { Elements of } \\
\text { opportunity }\end{array}$ & $\begin{array}{l}\text { Self-employment opportunities; } \\
\text { Opportunities "exist in pre-existing markets } \\
\text { or industries. Clearly definable market } \\
\text { gaps. Exist whether an entrepreneur } \\
\text { exploits them or not" [76]; } \\
\text { There are opportunities "to be actualized } \\
\text { into profits through the introduction of } \\
\text { novel products or services" [77]. }\end{array}$ & $\begin{array}{l}\text { Fostering socially desirable behaviors; } \\
\text { Cultivating social capital; } \\
\text { Promoting community development; } \\
\text { Co-creating values of mutual benefits rather } \\
\text { than self-interest [78]; } \\
\text { Triggering and shaping "outcomes of a } \\
\text { variety of new venture creation attempts } \\
\text { across a range of actors" [52] (p. 676). }\end{array}$ \\
\hline $\begin{array}{l}\text { Theoretical } \\
\text { foundations }\end{array}$ & $\begin{array}{l}\text { Uncertainty and institutions of human } \\
\text { capital, property rights, and financial } \\
\text { capital for wealth creation and poverty } \\
\text { alleviation [76]. }\end{array}$ & $\begin{array}{l}\text { Effectuation theory [79], social } \\
\text { entrepreneurship [80], and actor-external } \\
\text { enabler nexus on opportunity [52]. }\end{array}$ \\
\hline Theoretical focus & $\begin{array}{l}\text { Focus on the entrepreneurial process and } \\
\text { value creation at the individual or } \\
\text { organizational levels [75]. }\end{array}$ & $\begin{array}{l}\text { Accumulation of multiple stakeholders, } \\
\text { entrepreneurs, and their interaction and } \\
\text { experiential learning to build social value } \\
\text { propositions. }\end{array}$ \\
\hline Level of analysis & Individual level & $\begin{array}{l}\text { Multiple levels: ecosystem (macro); } \\
\text { multiple stakeholder, entrepreneur, and } \\
\text { marginal poor/consumers (micro). }\end{array}$ \\
\hline $\begin{array}{l}\text { Means of making } \\
\text { opportunity }\end{array}$ & Discover/identify opportunity & $\begin{array}{l}\text { Enable/facilitate the actors (NGOs and the } \\
\text { poor) to exploit opportunities. }\end{array}$ \\
\hline $\begin{array}{l}\text { Purpose of } \\
\text { opportunity }\end{array}$ & $\begin{array}{l}\text { Exploiting the competitive imperfections to } \\
\text { pursue economic profits. }\end{array}$ & $\begin{array}{l}\text { Expanding opportunities for the poor } \\
\text { (outreach); Increasing social welfare for } \\
\text { inclusive growth. }\end{array}$ \\
\hline
\end{tabular}

We integrate the hybrid generative-partnership perspective into the co-creation [74] and institutional logics literature [81,82]. New agents and artifacts are generated in the social ecosystem to co-create agricultural co-brandings. All China Federation of Supply and Marketing Cooperatives, established in 1954, had built up a three-level business service network covering counties, townships, and villages in 2011. The new attribution generated from the network is that co-ops promote the participation of farmers in the integration and development of rural industries and enable the sharing of industrial-chain benefits. This new attribution contributes to the formation and development of the social ecosystem and makes it possible to mobilize farmers and firms to participate in co-branding building. Farmers are no longer the marginal part of the market, but rather the core contributor of the social ecosystem by generative partnership. Our generative partnership perspective significantly extends the literature on social innovation and inclusive innovation [83].

Third, we draw on two common schemas by participant observation of the inclusive business model in addition to interviews and archives. We use participant observation and the comparative method to study the two co-ops, to explore the agents, artifacts, and institutions of the social ecosystem, and to analyze the social ecosystem and generative partnership co-evolution. We spent six months at the research locations to develop trusting relationships with agents, to accurately describe their interactions, and to understand how the relationship is generated. Our participant observations are based on conversations with different agents in casual dialogue and semi-structural interviews. We then drew on the two schemas of the inclusive business model-i.e., the generative potentials [84] of partnerships and unexpected opportunities in co-creation, which also support the idea of market-creating innovations [10]. The two schemas show that the inclusive business model involves marginalized people in the value chain and creates social value propositions for them. 


\subsection{Managerial Implications}

There are three managerial implications based on our findings. The first implication is to link social innovations at the ecosystem level with a transformative environment in which each agent makes a living [83]. Generating new partnerships and designing artifacts could be scaffolded by new kinds of organization, such as hybrid organizations, and scaffolding structures accelerate innovations. Any agricultural innovation must consider environmental obstacles which farmers face. A small-scale economy only solves farmers' basic survival problem, but it does not help farmers integrate into global value chains. The new attribution of a co-op business model becomes the driving force of the inclusive ecosystem, because sharing benefits of value chains gradually helps farmers move up from the BOP. We find that the content, structure, and governance in this social business model are designable in an active system [18]. Reconfiguring the arrangement of these design elements could build partnership dynamics.

Second, exploring farmers' subjective activities could be helpful in revitalizing the rural economy, as farmers are the most important agents of the social ecosystem and the co-creation process $[85,86]$. Motivating farmers' enthusiasm could help improve local characteristic agricultural products, cooperate with enterprises to improve processing technology, and provide high-quality products for co-branding. Farmers are not only producers, but also consumers when they have increased income. They also become supporters and disseminators of co-branding. As Prahalad and Ramaswamy [86] (p. 9) suggested, "dialog, access, risk-benefits, and transparency are emerging as the basis for interaction" between consumers and firms. Third, at the start-up of co-branding, geographic concentration is important for the social ecosystem. Geographic concentration enables face-to-face interactions among agents-i.e., co-ops, farmers, firms, consumers, and local governments. With the co-branding development, especially at the scaling-up stage, social space plays a more important role than geographic space. Interactions could be described as local when the participants interact in the same community of practice, even if they are geographically remote. Local interactions are essential for agents to respond and create when the ecosystem is undergoing rapid changes. Since interactions taken together offer possibilities that help the social ecosystem to endure over time, the interactions are organized to recur spirally [87].

\subsection{Limitations and Future Research}

There are two limitations in this research. First, the history of co-brandings in China is short, so we cannot test for the long-term interactions among agents in the inclusive business model. Future research is needed to understand the long-term role and contribution of the inclusive business model in alleviating poverty and fostering rural development. Second, there were 91 agricultural co-brandings distributed in 20 provinces in China in 2018, among which Zhejiang province had 18 co-brandings, ranking as the top in the country. We chose two co-brandings initiated by the two co-ops in Zhejiang province as our research focus, but did not conduct a thorough survey involving all the co-brandings in China. Future research that involves a nationwide survey and an international comparison could further contribute to the generative relationship theory. Additionally, future work may also want to engage in empirical research of concept validity to test our constructs on generative partnership: directedness, heterogeneity, and interaction. Sophisticated social network analysis is necessary to further show the nuance of the generative-partnership snowball effect.

\section{Conclusions}

How are multiple partnerships among stakeholders formatted to solve a social problem? Extending the literature of inclusive growth and business models $(37,38,87)$, we developed a novel concept of generative partnership and identifies four stages in building hybrid generative partnerships in an inclusive business model. Our conceptualization and model significantly advance our understanding of social ventures and entrepreneurship in alleviating poverty. 
Author Contributions: Conceptualization, R.Z. and S.L.S.; Data curation, R.Z. and S.L.S.; Formal analysis, R.Z.; Funding acquisition, R.Z.; Investigation, R.Z. and S.L.S.; Methodology, R.Z. and S.L.S.; Supervision, S.L.S.; Writing - original draft, R.Z.; Writing - review \& editing, R.Z. and S.L.S. All authors have read and agreed to the published version of the manuscript.

Conflicts of Interest: The authors declare no conflict of interest.

\section{References}

1. Piketty, T.; Goldhammer, A. The Economics of Inequality; Harvard University Press: Cambridge, MA, USA, 2015.

2. Stiglitz, J.E. The Price of Inequality: How Today's Divided Society Endangers Our Future; Norton: London, UK, 2013.

3. Krugman, P. The Conscience of a Liberal; Norton: New York, NY, USA, 2007.

4. Gelles, D.; Yaffe-Bellany, D. Shareholder Value is no Longer Everything, Top C.E.O.s Say; Bus. Sect.; The New York Times: New York, NY, USA, 19 August 2019.

5. UNDP. Creating Value for All: Strategies for Doing Business with the Poor; United Nations: New York, NY, USA, 2008.

6. Silver, H. Social exclusion and social solidarity: Three paradigms. Int. Labour Rev. 1994, 133, 531-578.

7. Prahalad, C.K. The Fortune at the Bottom of the Pyramid: Eradicating Poverty through Profits; Wharton School Publishing: Philadelphia, PA, USA, 2005.

8. Hall, J.; Matos, S.; Sheehan, L.; Silvestre, B. Entrepreneurship and innovation at the base of the pyramid: A recipe for inclusive growth or social exclusion? J. Manag. Stud. 2012, 49, 785-812. [CrossRef]

9. Gradl, C.; Knobloch, C. Inclusive Business Guide: How to Develop Business and Fight Poverty; Endeva: Berlin, Germany, 2010; Available online: https://endeva.org/wp-content/uploads/2014/11/IBG_final.pdf (accessed on 1 February 2020).

10. Christensen, C.M.; Ojomo, E.; Dillon, K. The Prosperity Paradox: How Innovation Can Lift Nations out of Poverty; HarperCollins Publishers Inc: New York, NY, USA, 2019.

11. Soderstrom, S.B.; Weber, K. Organizational structure from interaction: Evidence from corporate sustainability efforts. Adm. Sci. Q. 2020, 65, 226-271. [CrossRef]

12. MacDonald, A.; Clarke, A.; Huang, L. Multi-stakeholder partnerships for sustainability: Designing decision making processes for partnership capacity. J. Bus. Ethics 2019, 160, 409-426. [CrossRef]

13. Hengst, I.A.; Jarzabkowski, P.; Hoegl, M.; Muethel, M. Toword a process theory of making sustainability strategies legitimate in action. Acad. Manag. J. 2020, 63, 246-271. [CrossRef]

14. Prahalad, C.K.; Hart, S. The fortune at the bottom of the pyramid. Strategy Bus. 2002, 26, 1-15. [CrossRef]

15. Karnani, A. Fortune at the bottom of the pyramid: A mirage. Calif. Manag. Rev. 2007, 49, 90-111. [CrossRef]

16. Brugmann, J.; Prahalad, C.K. Cocreating business's new social compact. Harv. Bus. Rev. 2007, 85, 80-90.

17. Chesborough, H.; Ahern, S.; Finn, M.; Guarrez, S. Business models for technology in the developing world: The role of non-governmental organizations. Calif. Manag. Rev. 2006, 48, 48-61. [CrossRef]

18. Zott, C.; Amit, R. Business model design: An activity system perspective. Long Range Plan. 2010, 43, $216-226$. [CrossRef]

19. Seelos, C.; Mair, J. Profitable business models and market creation in the context of deep poverty: A strategic view. Acad. Manag. Perspect. 2007, 21,49-63. [CrossRef]

20. London, T.; Hart, S.L. Reinventing strategies for emerging markets: Beyond the transnational model. J. Int. Bus. Stud. 2004, 35, 350-370. [CrossRef]

21. Raynor, J.; Cardona, C.; Knowlton, T.; Mittenthal, R.; Simpson, J. Capacity Building 3.0: How to Strengthen the Social Ecosystem. 2014. Available online: https://www.issuelab.org/resource/capacity-building-3-0-howto-strengthen-the-social-ecosystem.html (accessed on 20 December 2019).

22. Reed, A.M.; Reed, D. Partnerships for development: Four models of business involvement. J. Bus. Ethics 2008, 90, 3-37. [CrossRef]

23. Algoso, D. Feeling Frustrated by Your Job in Development? Become an Extrapreneur. The Guardian. 1 September 2015. Available online: https:/www.theguardian.com/global-development-professionalsnetwork/2015/sep/01/extraprenuer-frustrated-working-in-development-build-your-own-team-of-people (accessed on 5 June 2019). 
24. Battilana, J.; Dorado, S. Building sustainable hybrid organizations: The case of commercial microfinance organizations. Acad. Manag. J. 2010, 53, 1419-1440. [CrossRef]

25. Autio, E.; Thomas, L. Innovation ecosystems: Implications for innovation management. In The Oxford Handbook of Innovation Management; Dodgson, M., Gann, D.M., Phillips, N., Eds.; Oxford University Press: Oxford, UK, 2014.

26. Mair, J.; Marti, I.; Ventresca, M.J. Building inclusive markets in rural Bangladesh: How intermediaries work institutional voids. Acad. Manag. J. 2012, 55, 819-850. [CrossRef]

27. Ohanyan, A. NGOs, IGOs, and the Network Mechanisms of Post-Conflict Global Governance in Microfinance; Palgrave Macmillan: New York, NY, USA, 2008.

28. Clarke, A.; MacDonald, A. Ourcomes to partners in multi-stakeholder cross-sector partnerships: A resource-based view. Bus. Soc. 2019, 58, 298-332. [CrossRef]

29. Shepherd, D.A.; Williams, T.A.; Zhao, E.Y. A framework for exploring the degree of hybridity in entrepreneurship. Acad. Manag. Percpect. 2019, 33, 491-512. [CrossRef]

30. Austin, J.E.; Seitanidi, M.M. Collaborative value creation: A review of partnering between nonprofits and businesses. Part 2: Partnership processes and outcomes. Nonprofit Volunt. Sect. Q. 2012, 41, 929-968. [CrossRef]

31. Seitanidi, M.M.; Koufopoulos, D.N.; Palmer, P. Partnership formation for change: Indicators for transformative potential in cross sector social partnerships. J. Bus. Ethic 2010, 94, 139-161. [CrossRef]

32. Tracey, P.; Stott, N. Social innovation: A window on alternative ways of organizing and innovating. Innovation 2017, 19, 51-60. [CrossRef]

33. Lane, D.; Maxfield, R. Foresight, complexity, and strategy. In The Economy as an Evolving Complex System II; Arthur, W.B., Durlauf, S.N., Lane, D., Eds.; Westview Press: Bouler, CO, USA, 1997; pp. 169-198.

34. Russo, M.; Hughes, T.P. Complementary innovations and generative relationships: An ethnographic study. Econ. Innov. New Technol. 2000, 9, 517-558. [CrossRef]

35. Porter, M.; Kramer, M. Creating shared value. Harv. Bus. Rev. 2011, 1/2, 1-17.

36. Osterwalder, A.; Pigneur, Y. Business Model Generation: A Handbook for Visionaries, Game Changers, and Challengers; John Wiley \& Sons: Hoboken, NJ, USA, 2010.

37. George, G.; Bock, A.J. The business model in practice and its implications for entrepreneurship research. Entrep. Theory Pract. 2011, 35, 83-111. [CrossRef]

38. Hart, S.L. Capitalism at the Crossroads: Next Generation Business Strategies for a Post-Crisis World, 3rd ed.; Pearson Prentice Hall: Upper Saddle River, NJ, USA, 2010.

39. Adner, R.; Kapoor, R. Value creation in innovation ecosystems: How the structure of technological interdependence affects firm performance in new technology generations. Strateg. Manag. J. 2010, 31, 306-333. [CrossRef]

40. Shumate, M.; Hsieh, Y.P.; Oconnor, A. A nonprofit perspestive on business-nonprofit partnerships: Extending the symbiotic sustainability model. Bus. Soc. 2018, 57, 1337-1373. [CrossRef]

41. Dattée, B.; Alexy, O.; Autio, E. Maneuvering in poor visibility: How firms play the ecosystem game when uncertainty is high. Acad. Manag. J. 2018, 61, 466-498. [CrossRef]

42. Sun, S.L.; Chen, V.Z.; Sunny, S.A.; Chen, J. Venture capital as an ecosystem engineer for regional innovation co-evolution in an emerging market. Int. Bus. Rev. 2019, 28, 1-14. [CrossRef]

43. Adner, R. Match your innovation strategy to your innovation ecosystem. Harv. Bus. Rev. 2006, 84, 98-107.

44. Kapoor, R.; Lee, J.M. Coordinating and competing in ecosystems: How organizational forms shape new technology investments. Strateg. Manag. J. 2013, 34, 274-296. [CrossRef]

45. Jacobides, M.G.; Tae, C.J. Kingpins, Bottlenecks, and Value Dynamics Along a Sector. Organ. Sci. 2015, 26, 889-907. [CrossRef]

46. Azoulay, P.; Repenning, N.P.; Zuckerman, E.W. Nasty, Brutish, and Short: Embeddedness Failure in the Pharmaceutical Industry. Adm. Sci. Q. 2010, 55, 472-507. [CrossRef]

47. Repenning, N.P.; Sterman, J.D. Capability traps and self-confirming attribution errors in the dynamics of process improvement. Adm. Sci. Q. 2002, 47, 265-295. [CrossRef]

48. Pagani, M. Digital business strategy and value creation: Framing the dynamic cycle of control points. MIS Q. 2013, 37, 617-632. [CrossRef]

49. Ceccagnoli, M.; Forman, C.; Huang, P.; Wu, D.J. Cocreation of value in a platform ecosystem: The case of enterprise software. MIS Q. 2012, 36, 263-290. [CrossRef] 
50. Edelman, D.C.; Singer, M. Competing on customer journey. Harv. Bus. Rev. 2015, 93, 88-100.

51. Williamson, P.J.; De Meyer, A.D. Ecosystem Advantage: How to successfully harness the power of partners. Calif. Manag. Rev. 2012, 55, 24-46. [CrossRef]

52. Davidsson, P. Entrepreneurial opportunities and the entrepreneurship nexus: A re-conceptualization. J. Bus. Ventur. 2015, 30, 674-695. [CrossRef]

53. Davidsson, P.; Recker, J.; Briel, F.V. External enablement of new venture creation: A framework. Acad. Manag. Perspect. 2018. Available online: https://eprints.qut.edu.au/119185/ (accessed on 5 January 2020). [CrossRef]

54. Eisenhardt, K.M. Building theories from case study research. Acad. Manag. Rev. 1989, 14, 532-550. [CrossRef]

55. Yin, R.K. Case Study Research, 4th ed.; Sage: Thousand Oaks, CA, USA, 2009.

56. Welch, C.; Piekkari, R.; Plakoyiannaki, E.; Paavilainen-Mäntymäki, E. Theorising from case studies: Towards a pluralist future for international business research. J. Int. Bus. Stud. 2011, 42, 740-762. [CrossRef]

57. George, A.L.; Bennett, A. Case Studies and Theory Development in the Social Sciences; MIT Press: Cambridge, MA, USA, 2005.

58. Glaser, B.G.; Strauss, A.L. The Discovery of Grounded Theory: Strategies for Qualitative Research; Aldine Transaction: Chicago, IL, USA, 1967.

59. Gioia, D.A.; Corley, K.G.; Hamilton, A.L. Seeking qualitative rigor in inductive research: Notes on the Gioia methodology. Organ. Res. Methods 2013, 16, 15-31. [CrossRef]

60. Strauss, A.; Corbin, J. Basics of Qualitative Research: Techniques and Procedures for Developing Grounded Theory, 2nd ed.; Sage: Thousand Oaks, CA, USA, 1998.

61. Miles, M.B.; Huberman, A.M. Qualitative Data Analysis: An Expanded Sourcebook; Sage: Thousand Oaks, CA, USA, 1994.

62. Ricciardi, F.; Zardini, A.; Rossignoli, C. Organisational dynamism and adaptivebusiness model innovation: The triple paradox configuration. J. Bus. Res. 2016, 69, 5487-5493. [CrossRef]

63. Miller, D.; Friesen, P.H. Organizations: A Quantum View; Prentice Hall: Englewood Cliffs, NJ, USA, 1984.

64. North, D.C. Institutions, Institutional Change and Economic Performance; Cambridge University Press: Cambridge, UK, 1990.

65. Grief, A. Insitutions and the Path to the Modern Economy: Lessons from Medieval Trade; Cambridge University Press: Cambridge, UK, 2006.

66. Lane, D.; Maxfield, R. Ontological uncertainty and innovation. J. Evol. Econ. 2005, 15, 3-50. [CrossRef]

67. Lane, D.; Pumain, D.; Leeuw, S.E.V.D.; West, G. (Eds.) Complexity Perspectives on Innovation and Social Change; Springer: Berlin, Germany, 2008.

68. Prahalad, C.K.; Ramaswamy, V. Co-creating unique value with customers. Strategy Leadersh. 2004, 32, 4-9. [CrossRef]

69. Krackhardt, D.; Porter, L.W. The snowball effect: Turnover embedded in communication networks. J. Appl. Psychol. 1986, 71, 50-55. [CrossRef]

70. Brezis, E.; Verdier, T. Political institutions and economic reforms in Central and Eastern Europe: A snowball effect. Econ. Syst. 2003, 27, 289-311. [CrossRef]

71. Swierczek, A. The impact of supply chain integration on the "snowball effect" in the transmission of disruptions: An empirical evaluation of the model. Int. J. Prod. Econ. 2014, 157, 89-104. [CrossRef]

72. Foss, N.J.; Saebi, T. Fifteen years of research on business model innovation: How far have we come, and where should we go? J. Manag. 2016, 43, 200-227. [CrossRef]

73. Christensen, C.M.; Ojomo, E.; Dillon, K. Cracking frontier markets. Harv. Bus. Rev. 2019, 1/2, 90-101.

74. Alvarez, S.A.; Barney, J.B. Discovery and creation: Alternative theories of entrepreneurial action. Strateg. Entrep. J. 2007, 1, 11-26. [CrossRef]

75. Alvarez, S.A.; Barney, J.B. Entrepreneurial opportunities and poverty alleviation. Entrep. Theory Pract. 2014, 38, 159-184. [CrossRef]

76. Ramoglou, S.; Tsang, E.W.K. A realistic perspective of entrepreneurship: Opportunities as propensities. Acad. Manag. Rev. 2016, 41, 410-434. [CrossRef]

77. Zahra, S.A.; Newey, L.R.; Li, Y. On the frontiers: The implications of social entrepreneurship for international entrepreneurship. Entrep. Theory Pract. 2014, 38, 137-158. [CrossRef]

78. Read, S.; Dew, N.; Sarasvathy, S.D.; Song, M.; Wiltbank, R. Marketing under uncertainty: The logic of an effectual approach. J. Mark. 2009, 73, 1-18. [CrossRef] 
79. Mair, J.; Marti, I. Social entrepreneurship research: A source of explanation prediction, and delight. J. World Bus. 2006, 41, 36-44. [CrossRef]

80. Sun, S.L.; Im, J. Cutting microfinance interest rates: An opportunity co-creation perspective. Entrep. Theory Pract. 2015, 39, 101-128. [CrossRef]

81. Im, J.; Sun, S.L. Profits and outreach to the poor: The institutional logics of microfinance institutions. Asia Pac. J. Manag. 2015, 32, 95-117. [CrossRef]

82. Cobb, J.A.; Wry, T.; Zhao, E.Y. Funding financial inclusion: Institutional logics and the contextual contingency of funding for microfinance organizations. Acad. Manag. J. 2016, 59, 2103-2131. [CrossRef]

83. Lee, R.P.; Spanjol, J.; Sun, S.L. Social innovation in an interconnected world: Introduction to the special issue. J. Prod. Innov. Manag. 2019, 36, 662-670. [CrossRef]

84. Sun, S.L.; Zou, B. Generative capability. IEEE Trans. Eng. Manag. 2019, 66, 636-649. [CrossRef]

85. Voorberg, W.H.; Bekkers, V.J.J.M.; Tummers, L.G. A systematic review of co-creation and co-production: Embarking on the social innovation journey. Public Manag. Rev. 2015, 17, 1333-1357. [CrossRef]

86. Prahalad, C.K.; Ramaswamy, V. Co-creation experiences: The next practice in value creation. J. Interact. Mark. 2004, 18, 5-14. [CrossRef]

87. Sun, S.L.; Xiao, J.; Zhang, Y.; Zhao, X. Building business models through simple rules. Multinatl. Bus. Rev. 2018, 26, 361-378. [CrossRef]

(C) 2020 by the authors. Licensee MDPI, Basel, Switzerland. This article is an open access article distributed under the terms and conditions of the Creative Commons Attribution (CC BY) license (http://creativecommons.org/licenses/by/4.0/). 